\title{
PREDICTION OF DRAGON'S BLOOD TREE (DRACAENA CINNABARI BALF.) STAND SAMPLE DENSITY ON SOQOTRA ISLAND
}

\author{
IRENA HUBÁLKOVÁ \\ Mendel University in Brno, Faculty of Forestry and Wood Technology, Department of \\ Forest Botany, Dendrology and Geobiocoenology, Zemědělská 3, 61300 Brno, Czech \\ Republic irena.hubalkova@mendelu.cz
}

Received: $1^{\text {st }}$ March 2011, Accepted: $11^{\text {th }}$ July 2011

\begin{abstract}
Dracaena cinnabari Balf. On The Soqotra Island is a spectacural relict of the Tethys tropical forest. This unique endemic plant, producing medicinally valuable sap, used to cover larger areas in the past. Natural regeneration of this species is restricted to inaccessible localities with steep slopes. All seedlings are threatened by goats grazing. Age structure of Dracaena populations indicates maturity and overmaturity depending on browsing.

The objective of this work is to predict growing dynamics of Dragon's Blood Trees in permanent sample plot at Firmihin, where there is the largest existing stand of Dracaena species. The prediction and visualization of variation in abundance of trees over 100 years is based on direct field measurements supported by mathematical calculations. The study presents options in forest regeneration and identifies threats that might occur during the implementation.
\end{abstract}

Key words - Dracaena cinnabari, Soqotra, stand visualization, trees density prediction

\section{INTRODUCTION}

The Soqotra Archipelago (see Fig. 1) is situated in the northwestern part of the Indian Ocean. It consists of two main islands: Soqotra (also written Sokotra, Socotra, Suqutra) and Abdalkuri (Abd El Kuri), two smaller ones, Samhah and Darsa, called The Brothers, and of the rocks of Cal Farun and Hertha (Mies and Beyhl, 1996). Politically, this archipelago belongs to the Republic of Yemen. With an area of $3625 \mathrm{~km}^{2}$ Soqotra is the largest island in the Arab world (Elie, 2002), it lies about $235 \mathrm{~km}$ east of the Horn of Africa $\left(12^{\circ} 18^{\prime}-12^{\circ} 42^{\prime} \mathrm{N}\right.$ latitude and $53^{\circ} 18^{\prime}-54^{\circ} 32^{\prime} \mathrm{E}$ longitude); the highest altitudes can be found in Haghier Mountains (over $1500 \mathrm{~m}$ a. s. 1.). 
Fig. 1: Geographical location of Soqotra Island.
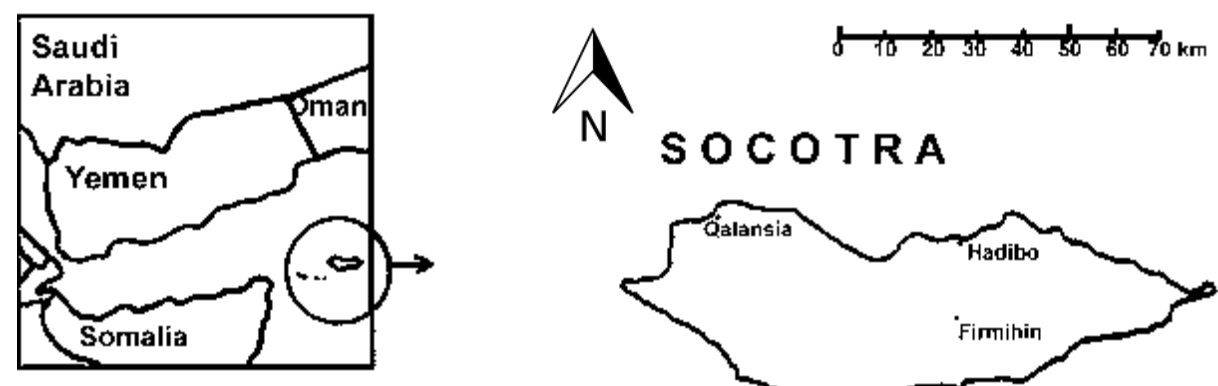

Many authors have provided information regarding climate on Soqotra, but this information seems to be based on individual experiences during short-term stays on the island or derived from wider climatic characteristics of the Indian Ocean or nearby mainlands (Habrová, 2007). According to Mies and Beyhl (1996), the islands are situated in the arid tropical zone where evapotranspiration generally exceeds precipitation by far. The climate of the ecoregion is influenced by the southwest (summer) and northeast (winter) monsoons. The south-west monsoon (May to September) brings only humidity, the northeast monsoon (November to March) is milder but brings regular winter rain (Fleitmann et al., 2007). For the rest of the yearonly dry weather conditions can be expected.

Table 1: Annual statistics of 'daily mean values' of selected climatic variables calculated from completed values in 'ideal year' (2000-2004) at Firmihin locality (Král, 2005).

\begin{tabular}{|l|c|c|c|}
\hline \multicolumn{1}{|c|}{ Variable } & Min & Max & Mean \\
\hline Air temperature $\left[{ }^{\circ} \mathrm{C}\right]$ & 19.3 & 28.9 & 23.7 \\
\hline Air humidity $[\%]$ & 36.6 & 99.5 & 72.6 \\
\hline Wind speed [m/s] & 0.3 & 8.2 & 2.6 \\
\hline Precipitation [mm/day] & 0.0 & 207.5 & 1.1 \\
\hline
\end{tabular}

The Soqotra Island is undoubtedly one of themost precious natural assets, not only for the Republic of Yemen, but for many people around the world (Yucer, 1988). In 2003, the archipelago was declared the first biosphere reserve under the UNESCO Man and the Biosphere Program in Yemen, because Soqotra Island was recognised as one of the best preserved island ecosystems on Earth (Miller et al., 2006). Habrová et al. (2009) mentioned that the island was listed as a World Heritage Site in 2008. Separated from continent during the Tertiary period the island supports no indigenous mammals, but its floral endemism rate makes it one of the most biodiverse islands in the world (Grant, 2005). There are 825 species of flowering plants and ferns recorded on the archipelago, out of which 12 genera and 307 species (37\%) are thought to be endemic (Miller et al., 2006). According to Buček et al. (2004), the majority of woody species forming natural forest, woodland and/or shrub communities is also endemic. Significant among these are arborescent frankincense trees (Boswellia sp.), myrrh trees (Commiphora sp.), arborescent spurges (Euphorbia sp.), a rare 
endemic shrub Dirachma socotrana and the only known wild pomegranate species (Punica protopunica). Succulent woody species, particularly the endemic cucumber tree (Dendrosycios socotrana), desert rose (Adenium obesum ssp. socotranum) and the endemic Dorstenia gigas characterize the island of Soqotra. The unique vegetation formation is the evergreen woodland dominated by the famous Dragon's Blood Tree (Dracaena cinnabari), Soqotra's most iconic plant (Miller at al., 2006). Soqotra Island is justifiably compared with Mauritius, the Galapagos or the Canary Islands. This is due to its floristic richness and level of endemism. Fauna of Soqotra is comparably rich in species although not yet fully substantiated.

For thousands of years, the people of Soqotra have lived with and used the biological resources in a sustainable manner (Mies and Beyhl, 1996) harvesting only what they needed and practising rotational grazing (Miller et al., 2006). However, the Soqotra Archipelago, with an estimated human population ranging from 40,000 to 80,000 people, is described as one of the poorest and most disadvantaged groups of islands anywhere in the world (Elie, 2002). Majority of people is concentrated in the capital of Hadiboh and in its surroundings. They speak Soqotri and Arabic. The people are sustained by fishing, livestock (mainly goats) and small scale agricultural produce, particularly dates (Ceccolini, 2000). Since ancient times the island was famous for its Dragon's Blood, obtained from the sap of Dracaena cinnabari, (Mies and Beyhl, 1996). Nowadays, the island is losing its isolation rapidly. This is due to industrial development and tourism.

The genus Dracaena comprises 60 to 100 species and recent taxonomic ambiguity has resulted in its classification to three families, i.e. Agavaceae, Liliaceae and Dracaenaceae, the latter is a family formerly comprising the other two (Adolt and Pavliš, 2004). Representatives of the Dracaena genus have survived in woodlands on dry margins of the Tethys tropical forest since the Tertiary Period. Most of the Dracaena species grow as shrubs or geophytes, often with ornamental potential (Adolt and Pavliš, 2004). Some species exhibit the growth habit of a tree : Dracaena cinnabari Balf. on Soqotra, Dracaena serrulata Baker in Southwestern Arabia, Dracaena ombet Kotschy \& Peyr in Eastern Africa, Dracaena schizantha Baker on Macaronesian Islands, Dracaena draco L. in Moricci, Dracaena tamaranae A. Marrero, R.S. Almeina and M. Gonzáles-Martín on the Canary Islands and Dracaena steudneri Engl. in Ethiopia and Eastern Africa (Bekele, 2007).

Dracaena cinnabari is an evergreen tree with a typical umbrella-shaped crown due to a "dracoid" ramification of branches (Adolt and Pavliš, 2004). Dracaena species are exceptional among monocotyledonous plants because of their capacity for secondary thickening of stems and roots (Habrová et al., 2009). The area of distribution of Draceana species ranges from the altitude of $150 \mathrm{~m}$ to $1,600 \mathrm{~m}$ above sea level, predominantly above $600 \mathrm{~m}$ a. s. 1. (Petroncini, 2001). Dragon's Blood Tree is not widely spread over the Soqotra Island. It is restricted to the area of the large central plateau of Diksam, the central granite massive of Haggeher and the eastern area of Hamadero, Sirahon and Kilisan (Petroncini, 2001). Plant density is not homogenous. Analyses show that the area of Dracaena woodland land-cover class on Soqotra reaches 3,658 ha, i. e. $1.1 \%$ of the total area of the island (Král and Pavliš, 2006). Natural seeding is restricted to inaccessible places with steep slopes.

Longterm research conducted by the Mendel University team from Brno has generated important data regarding ecophysiology, phenology, morphology, growth characteristics, estimation of age, population dynamics of Dracaena cinnabari, site conditions or species composition. Precise geobiocoenological differentiation was created for recognition of the detailed state of natural conditions of the island (Buček, 2003). The Mendel University 
team also installed a weather station including an automatic data logger at Firmihin in November 2000, at an approximate altitude of $440 \mathrm{~m}$ above sea level. According to Habrová (2007), it is clear that only a long-term, continuous period of measurement at different locations on the island can lead to a better understanding of its present climate. That is why additional 5 mini-stations measuring only air temperature and air humidity were placed at different locations in 2004 (one of these 5 mini-stations has been stolen on Skant just after one month).

Research suggests that the population of Dracaena cinnabari is ageing and stands density is decreasing. There is an absence of natural regeneration on most sites of its natural range. The species is threatened mainly by omnipresent goat grazing, extraction of blood-red sap and fuelwood harvesting.

\section{MATERIAL AND METHODS}

\section{Data collection and field research}

Data, concerning the Soqotra Archipelago and Dracaena cinnabari, were focused on general information about the Dracaena genus and the Soqotra's most iconic plant Dracaena cinnabari (growth habit, distribution, utilization and its importance). Connections to causes of threats to this species were also mentioned.

Field surveys took place at Firmihin, where the largest homogenous stand of Dragon's Blood Trees was identified. One square sample plot of the youngest trees with the side length of $100 \mathrm{~m}$ was chosen. An inventory of 114 Dracaena trees within the sample plot was created. The equipment used was a measuring tape for girth in $1.3 \mathrm{~m}$ and crown diameter; Silva hypsometer, camera and a field notebook. Usage of laser rangefinder was expected, but the instrument was confiscated by soldiers at the airport in the capital of Yemen. All trees were photographed. The central point of sample plot was located by GPS Trimble-Juno SB and stabilized by a metal stake.

\section{Data processing}

Collected data were compiled in Microsoft Office Program Excel, copied to electronic note pad and applicated to Stand Visualization System (SVS). The data applicable to SVS consist of a simple stand spread sheet containing species, diameter at breast height (DBH) in $\mathrm{cm}$, height in $\mathrm{m}$, ratio (= crown height/tree height in $\mathrm{m}$ ), crown radius in $\mathrm{m}, \mathrm{X}$ and $\mathrm{Y}$ coordinates (longitude and latitude). In addition to these parameters a 'sausage-shape' sections of branches (see Fig. 3) and circumferential inflorescence were calculated during the fieldwork. Extra columns of Tree class and Crown class were added in Microsoft Office Program Excel. These are necessary for processing in SVS.

In general, 100 tables for 100 year prediction of this sample plot were generated. Prediction of trees sample density was developed on basis of previous long-term measurements and statistical evaluation made by members of the Mendel University team (Adolt and Pavliš, 2004) at Firmihin.

Next step consisted of division of all trees into 16 age categories by Habrová (2005) (Tab. 3). The categories were named from DR16 (seed) to DR1 (the oldest trees). The number of trees in particular category provided the vector of a population (Habrová et al., 2009). The age period of one branch section covers about 19 years (Adolt and Pavliš, 2004). It was necessary to predefine tree habits with different species codes in Tree Designer of SVS (see Fig. 2). The auxiliary view in SVS Tree Designer was used to display 
trees as they appear in an SVS image. Every created tree form was marked with assigned species code, which allows user to make changes to the form definition parameters. The tree class list shows all the tree class values currently represented for the current species. The crown class list shows all crown class values currently represented for the current species and current tree class. It was necessary to create a new plant form for Dracaena sp. based on an existing one. Usable form was selected and then the species, tree class and crown class for the new plant shape were modified.

According to SVS Manual created by McGaughey (2002), SVS generates images depicting stand conditions represented by a list of individual stand components (e. g. trees, shrubs) using detailed geometric forms. The images produced by SVS provide a readily understood representation of the stand conditions.

Fig. 2: Modeling of tree age classes in SVS Tree Designer.

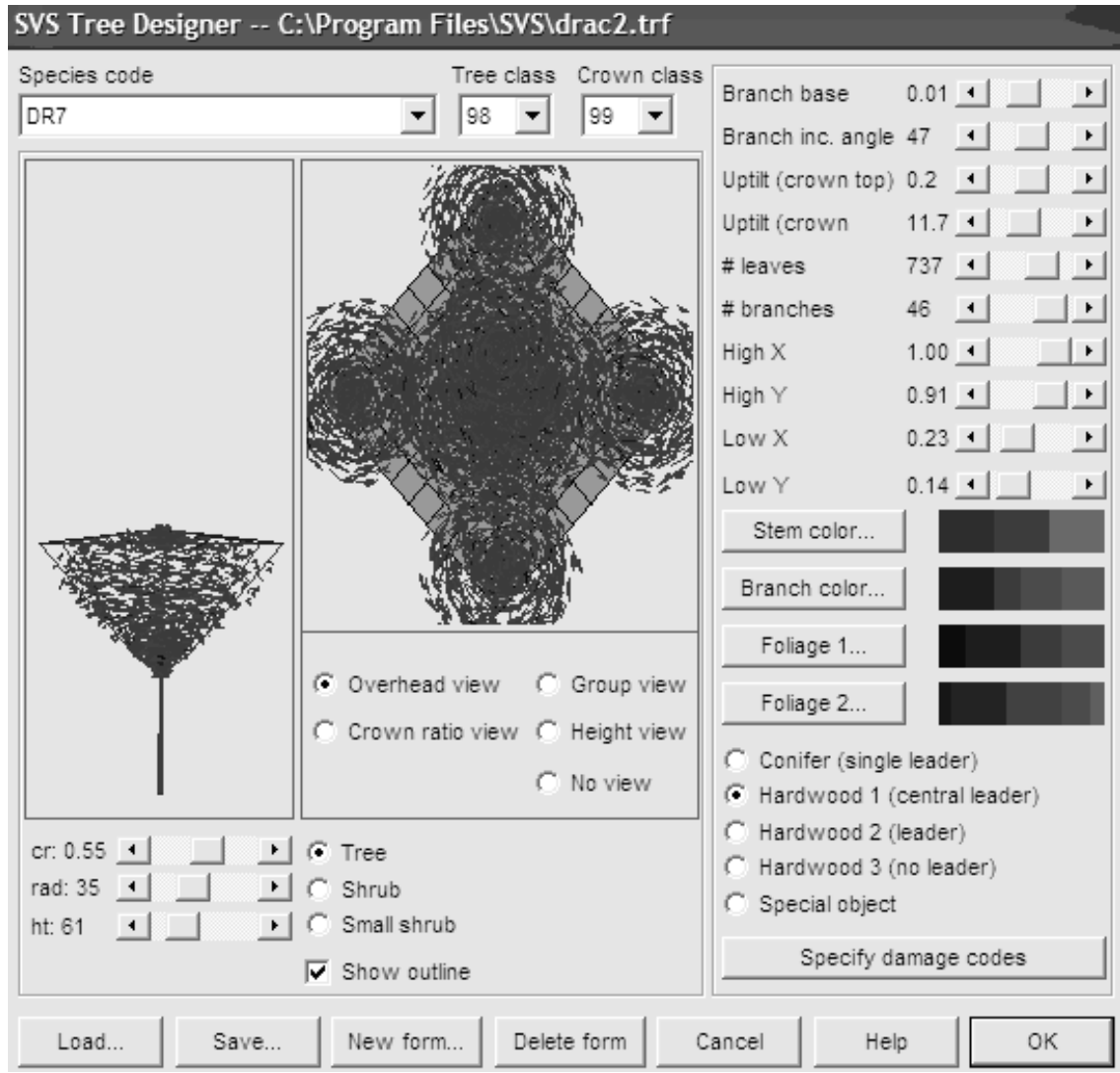

In order to construct a model of population development in the following years, it was necessary to compile a generally applicable matrix created by Habrová et al. (2009). The matrix (Tab. 2) is constructed of values for the probability of dying out within a given age category and the value of the average age of one section of a branch. The values along the diagonal give the probability that a plant will persist in the same category during one year. The matrix was multiplied by a particular vector in a numerical computing environment MATLAB (i.e., by the actual number of trees in particular categories). Graph 
expressing the decrease in the number of trees during 100 years was created in MATLAB by the above mentioned multiplying of the matrix and vectors.

Table 2: Matrix and the vector (= real number of trees fallen into each category for a given "number of narrowed branch sections").

\begin{tabular}{|c|c|c|c|c|c|c|c|c|c|c|c|c|c|c|c|}
\hline & 1st flower & $1-2$ & $3-4$ & $5-6$ & $7-8$ & $9-10$ & $\mid 11-12$ & $13-14$ & $15-16$ & $\mid 17-18$ & $19-20$ & \begin{tabular}{|l|}
$21-22$ \\
\end{tabular} & $23-24$ & $25<$ & Vector \\
\hline 1st flower & 0,98824 & 0 & 0 & 0 & 0 & 0 & 0 & 0 & 0 & 0 & 0 & 0 & 0 & 0 & 4 \\
\hline $1-2$ & \begin{tabular}{|l|}
0,01176 \\
\end{tabular} & 0,97368 & 0 & 0 & 0 & 0 & 0 & 0 & 0 & 0 & 0 & 0 & 0 & 0 & 2 \\
\hline $3-4$ & 0 & 0,02632 & 0,97178 & 0 & 0 & 0 & 0 & 0 & 0 & 0 & 0 & 0 & 0 & 0 & 8 \\
\hline $5-6$ & 0 & 0 & 0,02626 & 0,97206 & 0 & 0 & 0 & 0 & 0 & 0 & 0 & 0 & 0 & 0 & 16 \\
\hline $7-8$ & 0 & 0 & 0 & 0,02627 & 0,97125 & 0 & 0 & 0 & 0 & 0 & 0 & 0 & 0 & 0 & 22 \\
\hline $9-10$ & 0 & 0 & 0 & 0 & 0,02625 & 0,97251 & 0 & 0 & 0 & 0 & 0 & 0 & 0 & 0 & 17 \\
\hline $11-12$ & 0 & 0 & 0 & 0 & 0 & 0,02628 & 0,96975 & 0 & 0 & 0 & 0 & 0 & 0 & 0 & 19 \\
\hline $13-14$ & 0 & 0 & 0 & 0 & 0 & 0 & 0,02621 & 0,96822 & 0 & 0 & 0 & 0 & 0 & 0 & 16 \\
\hline $15-16$ & 0 & 0 & 0 & 0 & 0 & 0 & 0 & 0,02617 & 0,96801 & 0 & 0 & 0 & 0 & 0 & 4 \\
\hline $17-18$ & 0 & 0 & 0 & 0 & 0 & 0 & 0 & 0 & 0,02616 & 0,96619 & 0 & 0 & 0 & 0 & 4 \\
\hline $19-20$ & 0 & 0 & 0 & 0 & 0 & 0 & 0 & 0 & 0 & 0,02611 & 0,96354 & 0 & 0 & 0 & 0 \\
\hline $21-22$ & 0 & 0 & 0 & 0 & 0 & 0 & 0 & 0 & 0 & 0 & 0,02604 & 0,94713 & 0 & 0 & 0 \\
\hline $23-24$ & 0 & 0 & 0 & 0 & 0 & 0 & 0 & 0 & 0 & 0 & 0 & 0,02560 & 0,94270 & 0 & 1 \\
\hline $25<$ & 0 & 0 & 0 & 0 & 0 & 0 & 0 & 0 & 0 & 0 & 0 & 0 & 0,02548 & 0,95833 & 1 \\
\hline
\end{tabular}

\section{RESULTS}

The research was carried out on Firmihin, located in the central part of Soqotra Island. The dense Dracaena woodland found at Firmihin is unique in the world. Exact location of the stabilized central point of the sample plot is $X$ 175964,9968856; Y 1381889,1487503; Z 544,8 (WGS-84 reference system).

114 Dracaena trees were identified on the selected sample plot. On average, trees have had from 9 to 10 branch sections (see Fig. 3).

Table 3: Number of trees belonging to each age category.

\begin{tabular}{|c|c|c|}
\hline Marking of age category & Number of branch sections & Number of trees \\
\hline DR16 & seed & 0 \\
\hline DR15 & seedling & 0 \\
\hline DR14 & the first flowering plant & 4 \\
\hline DR13 & 1 and 2 & 2 \\
\hline DR12 & 3 and 4 & 8 \\
\hline DR11 & 5 and 6 & 16 \\
\hline DR10 & 7 and 8 & 22 \\
\hline DR9 & 9 and 10 & 17 \\
\hline DR8 & 11 and 12 & 19 \\
\hline DR7 & 13 and 14 & 16 \\
\hline DR6 & 15 and 16 & 4 \\
\hline DR5 & 17 and 18 & 4 \\
\hline DR4 & 19 and 20 & 0 \\
\hline DR3 & 21 and 22 & 0 \\
\hline DR2 & 23 and 24 & 1 \\
\hline DR1 & $25<$ & 1 \\
\hline
\end{tabular}

Fig. 3: Branches segregated by narrowed 'sausage-shape' sections (photo by author). 


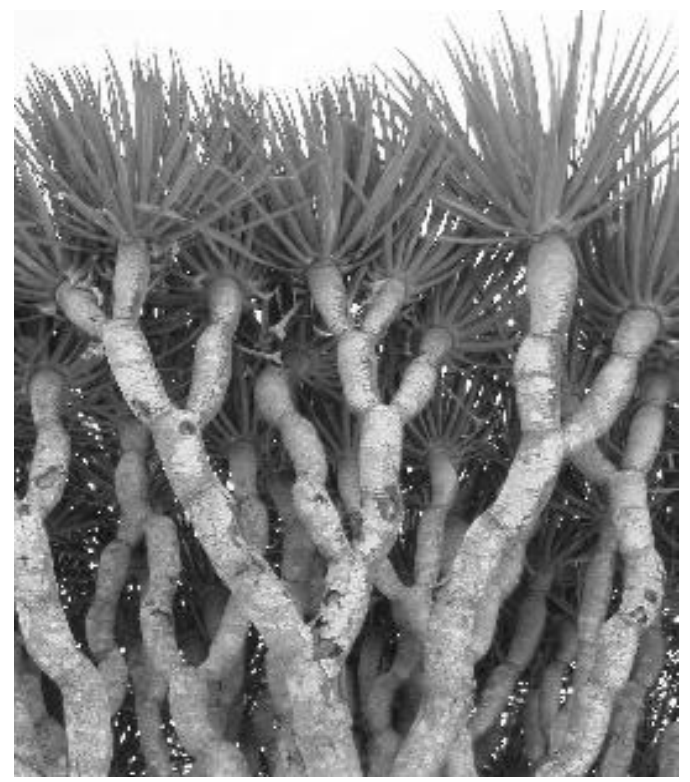

As mentioned above, 100 spread sheets for 100 year prediction of this sample plot were generated. The data in the first table showed the present condition of the trees (in the year 2010). The data in the hundredth table showed the same parameters 100 years later (in the year 2110). The diameter at breast height (DBH) has been averagely increasing by 0.053 cm per year and crown radius by 0.0089 m per year (Adolt and Pavliš, 2004).

Table 4: Parameters of Dracaena trees in 2010 displayed in electronic scratch pad.

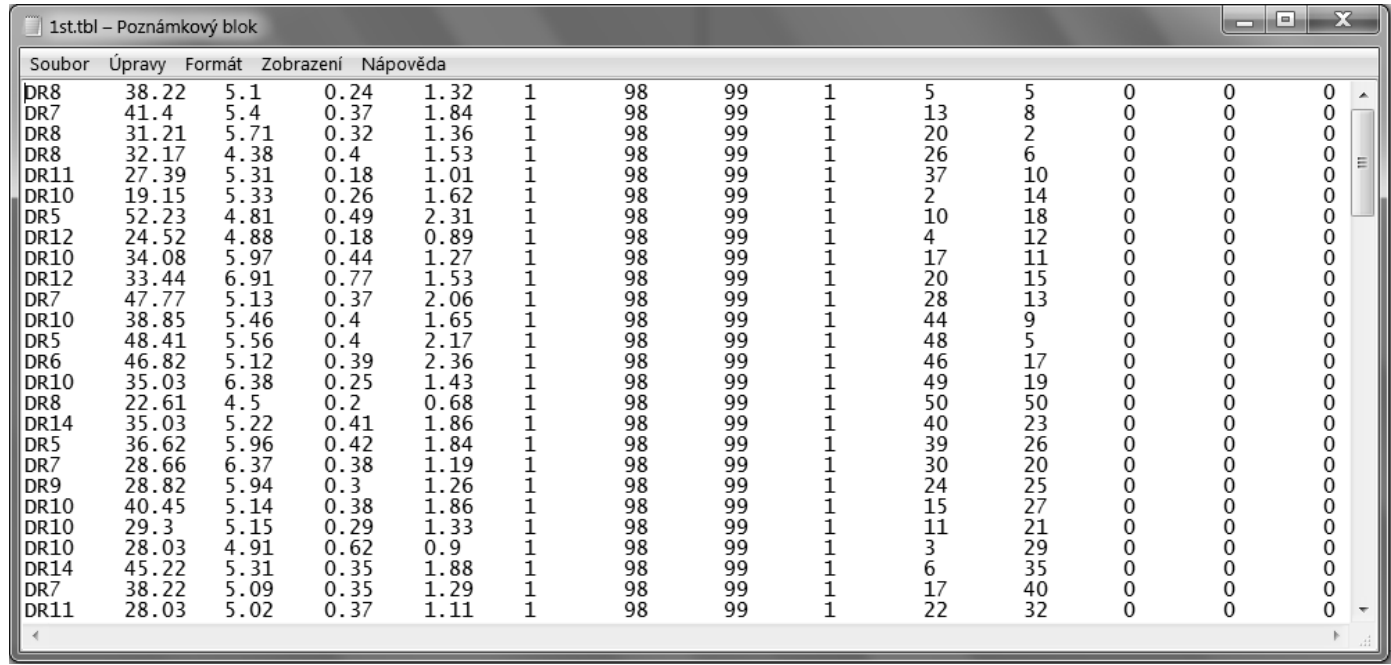


Graph (see Fig. 4) expresses prediction of tree density between 2010 and 2110. The graphical representation shows that from 114 trees approximately 73 trees should remain. Thus the number of trees would decrease by $36 \%$.

Fig. 4: Graph expressing the decrease in the number of Dracaena trees during 100 years; ten years interval between 0 and 100 is represented.

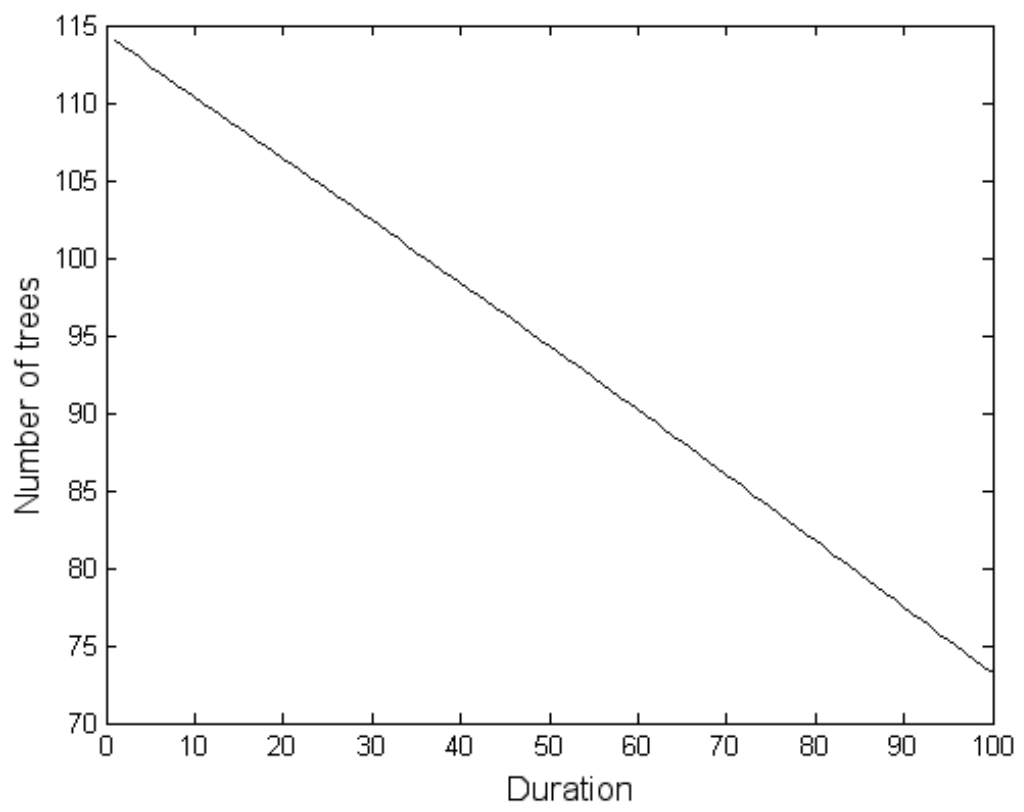

Two models were created in SVS on the basis of proven results. The first model shows the present condition of the trees (see Fig 5). The second model expresses the decrease in the number of trees during 100 years (see Fig. 6). The lowering number of the trees was chosen in consideration of age, vitality and degree of damage. The most frequent type of damage was permanently renewed stem scar caused by extraction of blood-red sap. Intensive goat grazing is expected. That is the reason why no natural regeneration and/or artificial plantation are included.

It is necessary to mention, that this prediction is very optimistic, because currently (in 2010) there are only the youngest Dracaena trees at Firmihin on the chosen sample plot. Natural disasters or other unexpected events are not assumed. 
Fig. 5: Model in SVS showing Dracaena trees sample density in 2010.

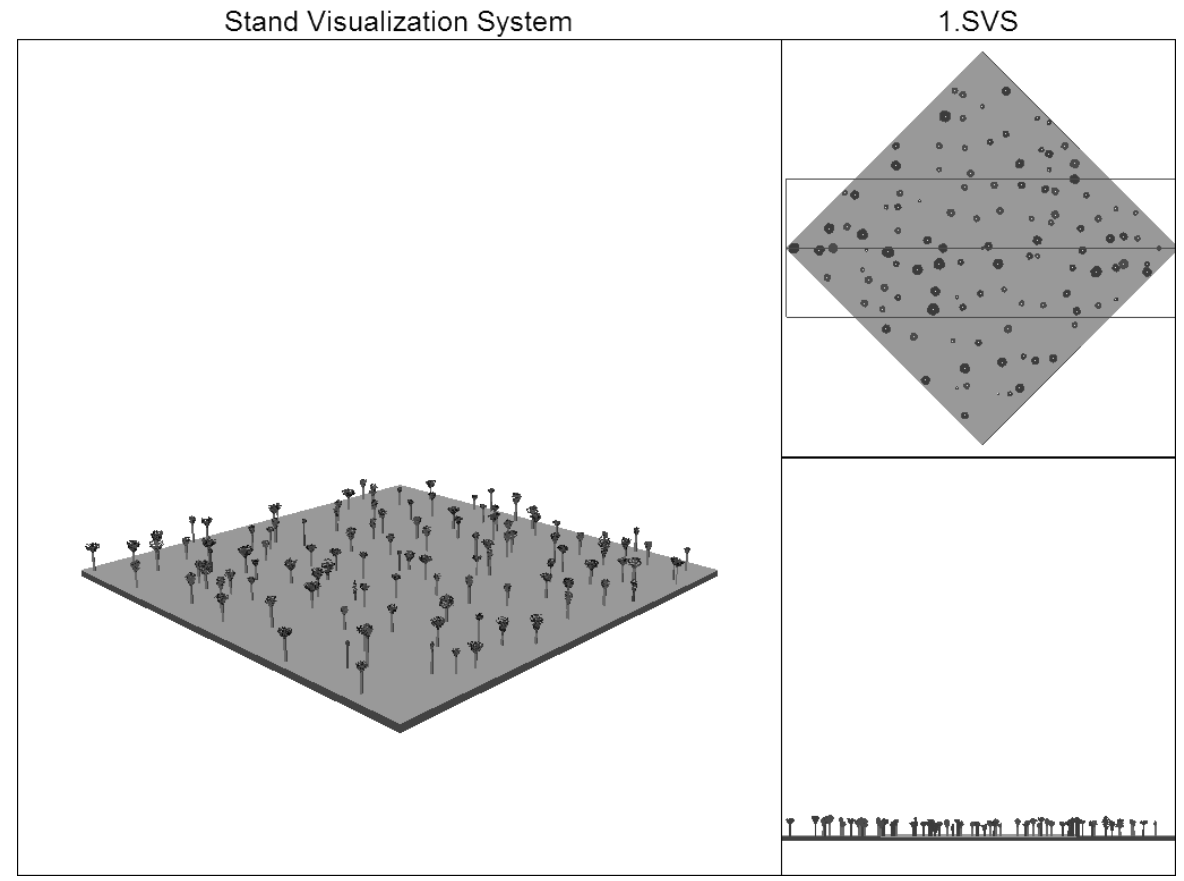

Fig. 6: Model in SVS showing Dracaena trees sample density in 2110.

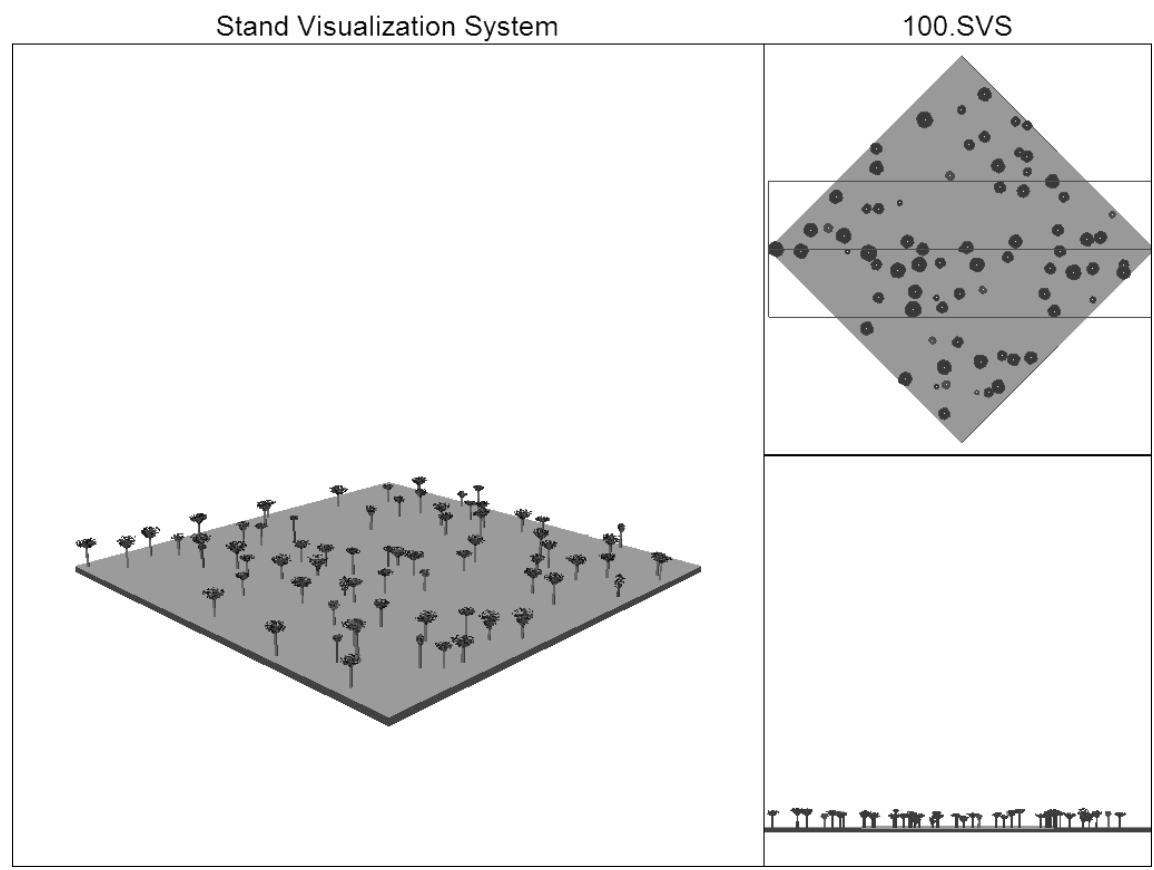




\section{DISCUSSION}

Age determination of monocotyledons in general is a very difficult task (Habrová et al., 2009). One study (Adolt and Pavliš, 2004) on the estimation of the age of Dracaena tree species has been published. According to the mentioned study, background is an indirect method reflecting relationship between the number of flowering periods and the actual age of a specimen. The relation can be well defined through specific branching of arborescent Dracaena species characterized by markedly swollen branches segregated individually by narrowed sections or 'sausage-shaped' sections. Based on this method, one branch section takes about 19 years to grow and Dracaena achieves age of up to 650 years. But even so it is hard to determine the age of stem before crown branching, because there are no growth rings in cross section of the stem. Habrová (2005) mentioned that there are three main growth stages in Dracaena's ontogeny. The seedling creates no trunk some time after germination, just a single rosette is growing and the number of leaves is increasing. After some time the trunk is formed but there is still only one single rosette on the top (Attorre et al., 2007). The branching and crown forming is related to the maturing stage (certain stem height) and ability to flower. Height growth cessation happens with ability to flower and occurs at height of between 40 and 1,200 cm (Habrová, 2005).

According to the method developed by Adolt and Pavliš (2004), the crown of the oldest tree on sample plot was 532 years old (28 branch sections). There were no seedlings without stem and only three young trees forming stem with no branching.

Based on statistical analyses as well as on direct field observations, Dracaena populations on Soqotra do not regenerate to a great extent and their age structure generally indicates overmaturity (Král and Pavliš, 2006). This research results confirm the claim by Adolt and Pavliš (2004) that with a $95 \%$ probability it is possible to expect that larger part of the world's most extensive Dracaena woodland complex at Firmihin will be in the stage of intensive disintegration within 30 to 77 years. Graphical representation as well as two models created by SVS show absence of natural regeneration. There are mostly middle aged trees on a sample plot, despite the fact that it is a locality with one of the youngest trees at Firmihin. The results demonstrate gradual degradation and disappearance of trees.

Some scientists (Attorre et al., 2007) attribute the reduction of the Dragon's Blood Tree to climate changes. According to Attorre et al. (2007), the predicted climate change may lead to a $45 \%$ loss of Dracaena potential distribution area by 2080 . The study published by Attorre et al. (2007) suggests that the original distribution of Dracaena cinnabari has been significantly reduced in the past. They hypothesise that a combination of factors may have contributed to its reduction (human activities, soil erosion, increased aridity and biotic interactions). They also suppose that current pattern of distribution, though fragmented may be primarily explained in terms of response to climatic constraints. Attorre et al. (2007) opine that Dragon's Blood Tree is able to colonise suitable areas if the present climatic conditions will remain stable and if a reduction of grazing and human pressure will occur.

Mendel University team does not consider climate change as a significant factor in the process of Dracaena tree reduction. We tend to believe that grazing by livestock, predominantly by goats, is the reason for its decline. Cattle grazing and excessive consumption of fuelwood and building timber most markedly represent an increasing anthropogenic pressure on natural resources of Soqotra (Buček, 2003). Seed production capability of Dragon's Blood Trees is optimal. However, thanks to the intensive browsing, there is the absence of natural regeneration except inaccesible steep slopes. The only way to prevent the decrease in stand density is a strict reserve and protection from grazing at Firmihin. The above mentioned solution appears unrealistic in the condisions of Soqotra 
Island where livestock grazing supports the majority of people. However, the only way to prevent the degradation and disappearance of trees is to prevent grazing damage.

The Dracaena woodland on Soqotra Island is rightly considered to be one of the oldest forest communities on Earth. It is a unique phytocoenose which used to cover larger area in the past. Mendel University team activities lead towards the promotion of Dracaena cinnabari regeneration, which include tree nursery establishement, endorsement and plants protection. The team is attempting to plant cultivated plants on the original localities of the species. Obstacles to succeed consist partially of the distrust of local people towards the foreigners, habitual way of traditional grazing management, long periods of dry weather conditions etc. It is necessary to support optimizing of Dragon's Blood Tree age structure.

\section{SUMMARY}

The aim of this study was to predict and visualize variation in the number of Dragon's Blood Trees over 100 years in a permanent sample plot at Firmihin on the Island of Soqotra. Field measurements were carried out in Firmihin, where the largest closed stand of Dracaena cinnabari was identified. One square sample plot of side lenght of $100 \mathrm{~m}$ in locality of the youngest Dragon's Blood Trees was chosen. The inventory of each tree in sample plot was carried out. Collected data were compiled in Microsoft Office Program Excel, copied to electronic scratch pad and applicated to Stand Visualization System (SVS). The prediction of growing dynamic was developed on basis of previous long-term measurements and statistical evaluation made by the Mendel University team. The mortality of trees during the next 100 years was evaluated, graphically figured out and the models of stand development were created on the basis of matrix indicating the probability of tree within branch section category persistance (Habrová et al., 2009).

114 Dracaena trees on a selected sample plot were identified. According to the method based on architectural age and statistical analyses published by Adolt and Pavliš (2004), the crown of the oldest tree was 532 years old ( 28 branch sections). The average trees have about 9 sections. There were no seedlings found without stem and only three young trees with created stem without branching. The graphical representation created in MATLAB shows that from 114 trees aproximately 73 trees will remain for the next100 years. Thus the number of trees will decrease by $36 \%$.

Two models were created in SVS on the basis of proven results. The first model shows trees sample density in 2010. The second model expresses the decrease in the number of 41 trees during 100 years. The curve (see Fig. 4) as well as two models created by SVS show absence of natural regeneration. Most likely this is due to livestock grazing, primarily by goats. The only way to prevent the degradation and disappearance of trees is to prevent grazing damage.

\section{ACKNOWLEDGEMENT}

This study was supported by IGA 12/2010, Faculty of Forestry and Wood Technology, Mendel University in Brno, Czech Republic. 


\section{REFERENCES}

Adolt R., Pavliš, J. (2004). Age structure and growth of Dracaena cinnabari populations on Socotra. Trees Structure and Function. Vol. 18, N. 1: 43-53 p.

Attore, F., Francesconi, F., Taleb, N., Scholte, P., Saed, A., Alfo, M. \& Bruno, F. (2007). Will dragonblood survive the next period of climate change? Current and future potential distribution of Dracaena cinnabari (Socotra, Yemen). Biological Conversation. Vol. 138, N. 3-4: 430-439 p.

Bekele, T. A. (2007). Useful Trees of Ethiopia: Identification, propagation and management in 17 Agroecological Zones. RELMA in ICRAF Project, Nairobi: 552 p.

Buček, A. (2003). Geobiocoenological Typology and Agroforestry as a Tool for Sustainable Development of Soqotra Island. Aden University Printing \& Publishing house, Aden: 97-108 p.

Buček, A., Habrová, H. \& Král, K. (2004). Geobiocenologická typologie ostrova Sokotry a její aplikace při tvorbě ekologické sítě. Fyzickogeografický sborník 2 - Kulturni krajina. Masarykova univerzita, Brno: 26-42 p. ISBN 80-210-3597-8.

Ceccolini, L. (2000). The home gardens of Soqotra. Florence: Department of Plant Biology-Laboratory, University of Florence, Retrieved 2010-06-05, from: WWW: < http://www.etfrn.org/ETFRN/newsletter/news36/nl36_oip7.html >.

Elie, S. D. (2002). A historical genealogy of Socotra as an object of mythical speculation, scientific research and development experiment. Brighton: The Centre for Culture, Development and Environment, University of Sussex, Retrieved 2010-02-25, from WWW: <http://www.aiys.org/webdate/socot.htmlM.

Fleitmann, D., Burns, S. J., Mangini, A., Mudelsee, M., Kramers, J., Villa, I., Neff, U., Alsubbary, A. A., Buettner, A., Hippler, D. \& Matter, A. (2007). Holocene ITCZ and Indian monsoon dynamics recorded in stalagmites from Oman and Yemen (Socotra). Quaternary Science Reviews. Vol. 26, N. 1-2: 170-188 p.

Grant, G. (2005). Socotra: Hub of the Frankincense Trade. Explorations: An Undergraduate Research Journal: 119-138 pp., Retrieved 2010-07-19 from WWW: <http://undergraduatestudies.ucdavis.edu/explorations/2005/grant.pdf>.

Gupta, D., Bleakley, B. \& Gupta, R. K. (2008). Dragon's blood: Botany, chemistry and therapeutic uses. Journal of Ethnopharmacology. Vol. 115, N. 3: 361-380 p.

Habrová, H. (2005). Geobiocenologická typologie a agrolesnictvi jako nástroj pro tvorbu ekologické sitě ostrova Sokotra (Jemenská republika). Dissertation. Department of Forest Botany, Dendrology and Geobiocoenology, Mendel University in Brno, Czech Republic..

Habrová, H. (2007). Climate of Soqotra with a View to Rais. Tayf - The Soqotra Newsletter. Vol. 4. 15-16 p.

Habrová, H., Čermák, Z. \& Pavliš, J. (2009). Dragon's blood tree - Threatened by overmaturity, not by extinction: Dynamics of a Dracaena cinnabari woodland in the mountains of Soqotra. Biological Conservation. Vol. 142, N. 4: 772-778 p.

Král, K. (2005). Assessment and mapping of forest and shrub geobiocoenoses by geoinformation methods. Dissertation. Department of Forest Botany, Dendrology and Geobiocoenology, Mendel University in Brno, Czech Republic..

Král, K., Pavliš, J. (2006). The first detailed land cover map of Socotra Island by Landsat /ETM+ data. International Journal of Remote Sensing. Vol. 27, N. 15: 3239-3250. ISSN 0143-1161. 
Mcgaughey, R. J. (2002). The Stand Visualization System Manual. USDA Forest Service, Pacific Nortwest Research Station, Retrieved 2010-05-18, from WWW: <http://forsys.cfr.washington.edu/winsvs/manual.pdf>.

Mies, B. A., Beyhl, F. E. (1996). The vegetation ecology of Soqotra. Soqotra Proceedings of the First International Symposium on Soqotra Island. (35-82 pp.). Present $\&$ Future. United Nations Publications, New York

Miller, A., ,Mrris, M., Wranik, W. \& Knees, S. (2006). Soqotra - Land of the Dragon's Blood Tree. Royal Botanic Garden Edinburgh, Edinburgh: 64 p. ISBN 1-872291-40-6.

Petroncini, S. (2001). Survey and monitoring of Dracaena cinnabari Balf. Fil. in Soqotra Island (Yemen). Florence: Department of Plant Biology-Laboratory, University of Florence, Retrieved 2010-06-08, from WWW: <http://www.etfrn.org/ETFRN/newsletter /news36/nl36_oip7.html >.

Yucer, O. (1988). Preface. Soqotra - Proceedings of the First International Symposium on Soqotra Island. (9-10 pp.). Present \& Future. United Nations Publications, New York 